\title{
Infection control in dentistry: how to asepsis photographic mirrors?
}

\author{
Amanda Osório Ayres de Freitas* Mariana Marquezan* Giselle \\ Naback Lemes Vilani* Rodrigo César Santiago* Luiz Felipe de \\ Miranda Costa* Sandra Regina Torres**
}

\begin{abstract}
The aim of this study was to evaluate the efficacy of six different methods of disinfection and sterilization of intra-oral photographic mirrors through microbiological testing and to analysis their potential harm to mirrors' surface. Fourteen occlusal mirrors were divided into seven groups. Group 1 comprised two mirrors as received from manufacturer. The other six groups comprised mirrors disinfected/sterilized by autoclave, immersion in enzymatic detergent, and friction with chlorhexidine detergent, chlorhexidine wipes, common detergent and 70\% ethylic alcohol. Microbiological and quality surface analyses were performed. Sterilization in autoclave was microbiologic effective, but caused damage to the mirror surface. Chlorhexidine (in wipes or detergent) and liquid soap were effective disinfectant agents for photographic mirrors decontamination, without harmful effect on its surface. Enzymatic detergent immersion and friction with $70 \%$ ethylic alcohol were not effective as disinfectant agents for photographic mirrors decontamination. According to the results, the more effective and safe methods for photographic mirrors disinfection were friction with chlorhexidine wipes or detergent, as well as liquid soap. Results, the most efficacious methods for photographic mirrors disinfection were friction with chlorhexidine wipes and detergent, as well as common detergent.
\end{abstract}

Descriptors: Dental Instruments; Decontamination; Microbiology; Surface Properties. 


\section{Introduction}

Dental photography is an important tool for diagnostic and treatment planning, and it's also a registration of the patient's condition before and after treatment. Therefore, good quality photographs must be prioritized and adequate mirrors must be used. Care must be taken during mirrors' cleaning to guarantee adequate decontamination avoiding cross infection and the production of scratches or stains. They should be decontaminated by sterilization or disinfection, but some of these methods may damage their surface, degrading the function performance.

According to the degree of risk for infection, photographic mirrors are categorized into except for oral surgery, when planning for disinfection and sterilization; which means that they might contact the intact mucosa or nonintact skin ${ }^{1,2}$. Autoclave is the best available method for sterilization at the dental office, but may be harmful to the quality of the surface of the photographic mirrors ${ }^{3}$. Disinfection with chemical agents is an acceptable option for semicritical items and glutaraldehyde (2\%) was considered the most widely used disinfectant for this purpose for many years. However, because of the health and safety concerns associated with glutaraldehyde use, several alternatives have been developed ${ }^{4}$. These include hydrogen peroxide, peracetic acid ${ }^{1}$, sodium hypochlorite, iodophors, phenolics, quaternary ammonium compounds $1,5,70 \%$ alcohol ${ }^{4}$, chlorhexidine and enzimatic detergent 5 .

The purpose of this study was to evaluate the efficacy of six different methods of disinfection and sterilization of photographic mirrors through microbiological testing and to analysis their potential harm to mirrors' surface.

\section{Materials and Methods}

Fourteen double side intra-oral occlusal photographic mirrors (Indusbelo ${ }^{\circledR}$, Londrina, Brazil) were used for this experiment and were divided into 7 groups. Group 1 comprised mirrors as receive from manufacturer. According to manufacturer's information, the mirrors were not previously disinfected or sterilized. The methods of application of the six disinfection products used in the other groups are listed on Table 1. Two mirrors were allocated for each group in order to obtain duplicated data. After treatment, the mirrors were evaluated according to the microbiological and damage surface aspects.

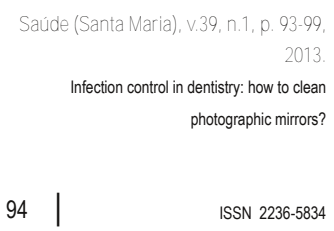


Table 1 - Group division according decontamination procedure.

\begin{tabular}{|c|c|c|}
\hline Group & Means of decontamination & Method applied \\
\hline Group 1 & $\begin{array}{l}\text { None } \\
\text { mirror evaluated as received } \\
\text { from manufacturer }\end{array}$ & None \\
\hline Group 2 & $\begin{array}{c}\text { Autoclave } \\
\text { (vertical autoclave Phoenix } \\
\text { AV-300, Phoenix Luferco, } \\
\text { Araraquara, Brazil) }\end{array}$ & $\begin{array}{l}\text { Autoclaved at } 120^{\circ} \mathrm{C} \text { for } \\
20 \mathrm{~min}\end{array}$ \\
\hline Group 3 & $\begin{array}{l}2 \% \text { digluconate chlorhexidine } \\
\text { detergent } \\
\text { (Rioquímica Ind Farm }{ }^{\circledR}, \text { São } \\
\text { José do Rio Preto, Brazil) }\end{array}$ & $\begin{array}{l}\text { Friction with sterile gauze } \\
\text { for } 3 \text { minutes*, followed by } \\
\text { washing with distilled water }\end{array}$ \\
\hline Group 4 & $\begin{array}{c}\text { Digluconate chlorhexidine } \\
\text { wipes } \\
\text { (Derma Plus, Campinas, } \\
\text { Brazil) }\end{array}$ & $\begin{array}{l}\text { Friction with sterile gauze } \\
\text { for } 3 \text { minutes }^{*}\end{array}$ \\
\hline Group 5 & $\begin{array}{l}\text { Enzymatic detergent } \\
\text { (Rioquímica Ind Farm }{ }^{\circledR}, \text { São } \\
\text { José do Rio Preto, Brazil) }\end{array}$ & $\begin{array}{l}\text { Immersion in solution for } 5 \\
\text { minutes, then wash in } \\
\text { distilled water }\end{array}$ \\
\hline Group 6 & $\begin{array}{c}\text { Commom detergent } \\
\left(\text { Limpol }^{\circledR}, \text { Bombril, São Paulo, }\right. \\
\text { Brazil) }\end{array}$ & $\begin{array}{l}\text { Friction with sterile gauze } \\
\text { for } 3 \text { minutes*, followed by } \\
\text { washing with distilled water }\end{array}$ \\
\hline Group 7 & $\begin{array}{c}70 \% \text { ethylic alcohol } \\
\text { (Miyako }{ }^{\circledR}, \text { Guarulhos, Brazil) }\end{array}$ & $\begin{array}{l}\text { Friction with sterile gauze } \\
\text { for } 3 \text { minutes* }^{*}\end{array}$ \\
\hline
\end{tabular}

The mirrors were submersed in $30 \mathrm{ml}$ of brain heart infusion broth (BHIB) in a $90 \times 15$ $\mathrm{mm}$ Petri dish and were incubated at $37^{\circ} \mathrm{C}$, for 24 hours. The contamination was determined by macroscopic observation of culture medium appearance. If the medium presented a turbid aspect after incubation, the mirror was considered contaminated.

The quality of the mirror surface was evaluated visually separately and blindly by two calibrated examiners (AOAF; MM). A Staining Index was created for this analysis that classifies it into 3 grades: 0 - no staining on the mirror; 1 - small staining that seems not to affect the quality of the photography; and 2- significant staining that might affect the quality of the photography. The Kappa statistic test (Quick Calcs, GraphPad Software Inc, San Diego, $\mathrm{CA}$, USA) showed total agreement between intra and inter-examiner $(\mathrm{k}=1)$. 


\section{Results}

A total of 28 mirror surfaces were evaluated. The photographic mirrors in the package were contaminated when they came from the manufacturer, as observed in the group not submitted to decontamination (Group 1). No previous sterilization method was described by the company.

In the microbiological evaluation of the mirrors, it was observed that all the mirrors submitted to common detergent, chlorhexidine detergent, chlorhexidine wipes and autoclave decontamination procedures were free from microbial colonization, presenting a clear culture medium. The growth media containing mirrors submitted to friction with $70 \%$ ethylic alcohol and immersion in enzymatic detergent were contaminated, presenting a turbid medium aspect, in both samples (Table 2).

\begin{tabular}{c|c} 
Table 2 - Results of the microbiological analysis of the mirrors after 6 different means of decontamination. \\
\hline Means of decontamination & \multicolumn{2}{|c}{ Staining Index } \\
\cline { 2 - 2 } Autoclave & Yes \\
Chlorexidine detergent & + \\
Chlorexidine wipes & + \\
Enzymatic detergent & + \\
Common detergent & + \\
$70 \%$ ethylic alcohol & + \\
\hline
\end{tabular}

Presence of contamination: (Yes) - turbid culture medium; (No) - clear culture medium.

Table 3 - Results of the mirrors surface analysis after 6 different means of decontamination.

\begin{tabular}{c|cc}
\hline Means of decontamination & \multicolumn{2}{|c}{ Staining Index } \\
\cline { 2 - 3 } & 0 & 1 \\
\hline Autoclave & & \\
Chlorexidine detergent & + & \\
Chlorexidine wipes & + \\
Enzymatic detergent & + \\
Common detergent & + \\
$70 \%$ ethylic alcohol & + \\
\hline
\end{tabular}

Staining Index: (0) - no mirrors'staining; (1) - small staining; (2) - significant staining

\section{Discussion}

The results of this study indicate a reduction in microbial contamination of photographic

Saúde (Santa Maria), v.39, n.1, p. 93-99,

Infection control in dentistry: how to clea photographic mirrors?
ISSN 2236-5834 mirrors when utilizing common detergent under friction during 3 minutes. Despite the fact that detergents are considered low-efficiency disinfectants, with restricted antimicrobial action, the main value of this method of cleaning probably was the manual friction (mechanical action) ${ }^{3}$. These detergents can inactivate certain viruses and bacteria in the vegetative form, but do not 
eliminate tuberculosis bacilli, hydrophilic viruses and fungi. The antimicrobial effect occurs mainly in the cellular membrane, by altering the osmotic barrier.

The chlorhexidine tested in this study was effective in reducing the microbial contamination of photographic mirrors. Chlorhexidine is a cationic bisbiguanide disinfectant which is popular for hand washing in healthcare establishments ${ }^{4}$, and for surgical preoperative preparation $^{4,6,7}$. It is mainly used as topical antiseptic, either aqueous or alcoholic solution, for its persistence in skin and mucosal surfaces. However its use as a disinfectant for devices is not well explored ${ }^{5}$. A study testing different disinfectants against human rotaviruscontaminated inanimate surfaces, observed marked efficacy of chlorhexidine for the disinfection of this virus ${ }^{8}$.

Detergents containing enzymes such as protease and amylase are suggested for the first cleaning step because of its increased efficacy in removing soil, allowing maximal biocide efficacy ${ }^{9,10}$. In this study, enzymatic detergents were used to clean the photographic mirrors immediately after it was removed from the package. The enzymatic detergent was not effective for this purpose. An important aspect to consider is that the enzymatic detergent might be more effective if the mirrors were contaminated by organic mouth. Another in vitro study showed a similar result. Fang et al $(2010)^{11}$ evaluated the cleanout of gastrointestinal endoscopes with distilled water, enzymatic and non-enzymatic detergent. It was found a better inhibition function on biofilm formation using non-enzymatic detergent. Enzymatic detergent was similar to water.

The $70 \%$ alcohol solution is one of the most used disinfectants in dental office. Alcohol is a disinfectant and antiseptic agent without sterilizing property. Ethylic and isopropyl alcohol have activity against bacteria in vegetative form, enveloped virus, mycobacteria and fungi. It does not present any action against spores and non-enveloped viruses. In general, isopropyl alcohol is considered more effective against bacteria, while ethylic alcohol is more potent against viruses ${ }^{10}$. The British Dental Association ${ }^{12}$ recommends $70 \%$ isopropyl alcohol for disinfecting contaminated surfaces under different circumstances. On the other hand, the $70 \%$ alcohol (ethylic or isopropyl) has no record at Environmental Protection Agency (EPA) and is not accepted by the American Dental Association (ADA ${ }^{13}$ as a disinfectant for fixed surfaces and instruments. Although there are studies showing a reduction on contanimation of medical devices using $70 \%$ alcohol for disinfection ${ }^{14}$, according to Venturelli et al (2009), the use of $70 \%$ ethylic alcohol is contraindicated to cross infection control in the dental office. Although they observed a reduction in microbial contamination of specific instruments, they concluded that this chemical agent cannot be recommended to decontaminate critical and semi-critical instruments. At the present study, the $70 \%$ ethylic alcohol was not effective in reducing the microbial contamination of the photographic mirrors and should not be indicated as an effective disinfectant for these devices.

It is important to emphasize that the disinfecting process might fail if the $\mathrm{pH}$ or temperature of the disinfectant is inappropriate ${ }^{15}$. Any chemical detergent used for coldsterilization should present neutral $\mathrm{pH}$. If a low $\mathrm{pH}$ value is applied, a breakdown of the stainless protective surface on the mirror might occur. On the other hand, a high $\mathrm{pH}$ value can cause a surface deposit of a brown stain which is not suitable. In our study, the solutions were kept in room temperature and the validity was not expired to avoid $\mathrm{pH}$ changes.

Campbell and Phendix ${ }^{16}$ recommended the sterilization in autoclave for most of the instrumental used in clinical practice, including photographic mirrors. Sterilization is the

Rev. Saúde (Santa Maria), v.39, n.1, p. 93 99, Jan/Jul. 2013. Freitas, A. et al. 
complete destruction of all viable micro-organisms including spores and virus. Autoclaving involves maintaining saturated steam at high temperature in a vacuum medium. It is used to eliminate all microbes including tuberculosis bacilli, viruses and heat-resistant spores. This method has excellent penetration with relatively short cycle time. However, the autoclaving procedure may damage plastic and rubber items and cause corrosion and oxidation of non stainless metal items ${ }^{3}$. The results of the present study indicated that autoclaving photographic mirrors was microbiologic effective, but harmful to the quality of the mirrors, due to the staining on their surfaces.

We considered sterilization harmful to the mirrors surface, while the use of chemical agents showed no damage after a single use. Based on these results, the recommendation is to avoid the sterilizing method for photographic mirrors, since they are semi critical articles and may be decontaminated by disinfection.

The results of this study will be useful to warn dentists that some dental instruments, as the photographic mirrors, may come contaminated in the package. If the manufacturer does not mention that the product is sterile, it is recommended to do a preliminary disinfection.

Further studies must be carried out to check if the tested methods are effective after contact with the organic matter of the patient's mouth. The mirror damage should also be tested after successive processes of disinfection.

Within the limitations of this study, it was possible to conclude that sterilization in autoclave is effective against microoganisms, but may damage the mirror surface. Chlorhexidine (in wipes or detergent) and liquid soap are effective disinfectant agents for photographic mirrors decontamination without harmful effect on its surface. And the $70 \%$ ethylic alcohol and enzymatic detergent are not effective as disinfectant agents for photographic mirrors decontamination.

\section{Acknowledgements}

The authors would like to express their thanks to the Brazilian Government through CAPES

(Coordenação de Aperfeiçoamento Pessoal de Nível Superior) for the financial support provided and Indusbelo for the donation of the mirrors.

\section{References}

1. Rutala WA, Weber DJ. Infection control: the role of disinfection and sterilization. J Hosp Infect. 1999; 43 (Suppl):S43-55.

2. Venturelli AC, Torres FC, Almeida-Pedrin RR, Almeida RR, Almeida MR, Ferreira FPC. Microbiological evaluation of residual contamination in different types of orthodontic pliers after disinfection with $70 \%$ alcohol. R Dental Press Ortodon Ortop Facial. 2009; 14 (4):43-52.

3. Alvarez-Leite ME, Pereira CRS. Cross-infection in dentistry. Prevention and control. Belo Horizonte: PUC Minas; 2007. p. 150 .

4. Springthorpe VS, Grenier JL, Lloyd-Evans N, Sattar SA. Chemical disinfection of human rotaviruses:

Saúde (Santa Maria), v.39, n.1, p. 93-99, 2013. efficacy of commercially-available products in suspension tests. J Hyg. 1986; 97(1):139-61.

5. Fraise AP. Choosing disinfectants. J Hosp Infect. 1999; 43(4):255-64.

6. Hoh CSL; Berry DP. Decontamination and Sterilization. Surgery. 2005; 23(8):282-284. 
7. Levin I, Amer-Alshiek J, Avni A, Lessing JB, Satel A, Almog B. Chlorhexidine and alcohol versus povidoneiodine for antisepsis in gynecological surgery. J Womens Health. 2011 Mar;20(3):321-4.

8. Lloyd-Evans N, Springthorpe VS, Sattar SA. Chemical disinfection of human rotavirus-contaminated inanimate surfaces. J Hyg. 1986; 97(1):163-73.

9. McBain AJ, Allison D, Gilbert P. Emerging strategies for the chemical treatment of microbial biofilm. Biotechnol Genet Eng Rev. 2000; 17: 267-9.

10. Santos AAM, Verotti MP, Sanmartin JA, Mesiano ERAB. Importance of alcohol on infection control in health services. Rev Adm Saúde. 2002; 4 (16): 7-14.

11. Fang Y, Shen Z, Li L, Cao Y, Gu LY, Gu Q, Zhong XQ, Yu CH, Li YM. A study of the efficacy of bacterial biofilm cleanout for gastrointestinal endoscopes. World J Gastroenterol. 2010 Feb 28;16(8):1019-24.

12. British Dental Association. 1989. Guide to blood borne viruses and the control of cross infection in dentistry.

13. Council on Dental Therapautics and Council on Prosthetic Services and Dental Laboratory Relations. Guideline for infection control in the dental office and the commercial dental laboratory. J Am Dent Assoc 1985; 110(6):969-72.

14. Uneke CJ, Ogbonna A, Oyibo PG, Onu CM. Bacterial contamination of stethoscopes used by health workers: public health implications. J Infect Dev Ctries. 2010 Aug 4;4(7):436-41.

15. Thompson,C. (2002) Health and safety issues pertaining to dental photographic mirrors and cheek and lip retractors. J Audiov Media Med. 2002; 25 (2): 54-8.

16. Campbell, PM; Phendix, N. Sterilization in the orthodontic office. J Clin Orthod. 1986; 20(10):684-6.

\section{Amanda Osório Ayres de Freitas}

Endereço para correspondência - Avenida Professor Rodolpho Paulo Rocco, 325. Ilha do Fundão, CEP 21941-617, Rio de Janeiro, RJ, Brasil.

E-mail: amandaoaf@gmail.com

Currículo Lattes: http://lattes.cnpq.br/4479531173275291

Recebido em 11 de abril de 2012.

Aprovado em 23 de julho de 2013. 